\title{
Smart kinesthetic measurement model in dance composision
}

\author{
${ }^{\otimes}$ Dinny Devi Triana
}

\author{
Department of Dance Education, Universitas Negeri Jakarta, Indonesia
}

Received: December 19, 2016. Revised: March 29, 2017. Accepted: April 15, 2017

\begin{abstract}
This research aimed to discover a model of assessment that could measure kinesthetic intelligence in arranging a dance from several related variable, both direct variable and indirect variable. The research method used was a qualitative method using path analysis to determine the direct and indirect variable; therefore, the dominant variable that supported the measurement model of kinesthetic intelligence in arranging dance could be discovered. The population used was the students of the art of dance department and were chosen by using purposive sampling technique so that the kinesthetic intelligence could be well measured. The result of this research was that the correlation between the ability in perceiving movement and the ability in conveying movement was 3.8048. The correlation between the ability in perceiving movement and kinesthetic intelligence was 0.3137 . The correlation between the ability in perceiving movement and arranging a dance was -0.3751 . The correlation between conveying movement and kinesthetic intelligence was 0.1333 . The correlation between conveying movement and arranging a dance was -0.2399 . The correlation between kinesthetic intelligence and arranging a dance was 0.8529 . These result proved that kinesthetic intelligence has significant influence to the ability in arranging a dance. It could be concluded that a smart assessment model of kinesthetic intelligence in arranging a dance that was needed should measure the kinesthetic intelligence first while the ability to perceive and convey movement became the supporting element to strengthen the kinesthetic intelligence in arranging a dance.
\end{abstract}

Keywords: measurement; perceiving movement; conveying movement; kinesthetic intelligence; arranging a dance

How to Cite: Triana, D. D. (2017). Smart kinesthetic measurement model in dance composision. Harmonia: Journal of Arts Research And Education, 17(1), 58-67. doi:http://dx.doi.org/10.15294/harmonia.v17i1.8257

\section{Introduction}

Kinesthetic intelligence cannot stand alone; it has a close relation to the cognitive ability of the human brain. A previous study related to the research had been done by Roberts, Stankov, Pallier, Dolph (1997) that categorized cognitive ability as kinesthetic ability inside human intelligence structure. This construction is actually a combination of two factors of mental velocity, they are: 1) time decision (DT - time that is used to determine and to accurately respond and is used as a stimulus), and 2) time movement (MT - the time that is related to censoric and motoric control). A similar result was also found by Almeida et al., (2010) in her research that stated the importance of education psychology, psychometric test, and culture in evaluating human intelligence by doing contextual assignment because the human intelligence consists of various cognitive aspects not only the verbal aspect and logic. Both

\footnotetext{
${ }^{\square}$ Corresponding author: Jl. Rawamangun Muka, RT.11/RW.14, Rawamangun, Jakarta Timur, 13220

E-mail: dinnydevi@unj.ac.id
} 
results proved that human intelligence is a complex cognitive structure and one of which is kinesthetic intelligence.

According to Bulmenfeld-Jones (2009) kinesthetic intelligence in dancing is not the ability to do a difficult movement, to memorize a sequence of movement, accuracy of movement, nor it is the ability to create a movement, but it is an ability of the human body to move in the way of thinking. Dancing and developing kinesthetic intelligence is self-actualization process, not the product of it. Talent and multi-intelligence that support cognitive, affective, and psychomotoric are part of the ability in arranging a dance because there are sense, feeling, and trial inside of it.

According to Gardner (2003) kinethetic inttelegence is the ability to finish a problem or product using whole or half parts of someone's body. Then, according to Amstrong (2002) kinesthetic intellegence consists of spesific physical abilities such as coordination, balance, skill, strength, flexibility, and speed. It also includes the ability to receive stimulus and jobs that involve touch such as craftman, scluptor, mechanic, surgeon. Based on the explanation above, it can be concluded that the core elements of the bodily-kinesthetic intelligence are control of one's bodily motions and capacity to handle objects skillfully (Grow, 2011) in which the core element of kinesthetic intellegence is the control of the movement to handle the object skillfully.

The kinesthetic intellegence is one of a psychological measurement tool that can be measured through attitude, Stankov (1999) revealed that someone's intelligence could be seen by judging his movement ability by using psychometry. This measurement is determined based on a particular unit of measure that is combined with a certain fact of the empirical object. As explained by Cangelosi (1995) measurement is a process of collecting data through empirical observation. Measurement is a set of rules for assigning numbers to represent objects, traits, attributes or behavior (Reynolds, Ronald, Victor, dalam Reynold, 2009). According to Sumadi (2000) the be- nefits of psychological measurement using quantitative approach are: 1) the measurement can be described clearly and accurately, 2) the order of thinking and work is systematic and consistant, 3) the measurement can be analyzed by using statistic, and the result can be predicted, 4) the degree of interchangeability is high because it is an open activity so it can be re-tested (Reynold, 2009). However, one of the disadvantages of quantitative-qualitative measurement is that it does not reflect the real condition, and even deviate from it. To resolve this problem, the measurement tool must guarantee the suitability of the qualitative data and the condition of the represented attribute.

Measuring the kinesthetic intelligence in arranging a dance is needed because the process of dance creation is related to the process of resolving the problem that is revealed through movement; therefore, the choreographer is responsive in solving the problem and creating new dance arrangement as the result of his creative thinking as described by Bloom (1979) in the theory of psychomotor. Meanwhile, Harrow described the kinesthetic as the ability in perceiving movement based on the purpose of the movement itself (Harrow, 1972).

In perceiving movement, integrating a physical function that coordinate between brain as the center of information and control is needed, in which the information is received and processed, then transferred by the motoric neurons to create movement. Hence, the interpretation captured as the information is known as interpretation. The ability to perceive movement is very useful in developing the achievement of cognitive, affective, and psychomotor domain in learning, especially in arranging a dance or choreography. This is an ability to interpret stimulus so that the decision making in facing the environment is easier. The stimulus received by the neurons to observe various movement variations in developing the perceptual ability depends on the ability to perceive information.

Rahantoknam (1968) in Dwiyantoro 
(2009) explained that there are two types of processing information, they are 1) the perception of given information. 2) the decision to do the motoric activity. Perception is a process of gathering, selecting, combining, organizing, and interpreting information. The function to perceive something efficiently is to develop effective, cognitive, and psychomotor domain that can support stimulus interpretation. Someone is able to adjust to his environment because the existence of the cognitive and psychomotor activity that refers to the ability in perceiving. It is clear that people should have maximum ability to act through stimulus and a chance to explore various movements as a medium to develop the perceptual ability in perceiving everything.

In dancing, this process is needed when responding to information that can divert control from perception to feeling so that it becomes a meaningful movement and has aesthetic and artistic value, in accordance with the definition of dancing as a rhythmic and beautiful movement. Based on that, in dancing, especially regarding the ability in arranging a dance, movement perception is needed. Because when information from the outside is captured as a movement response, the movement will be flawless, has characteristic, and even a theme. Similar to the statement of Blumenfeld-Jones, Gress, \& Purpel (2009) that movement response is not only needed to show movement, but it includes also the need to move, to feel the movement, and to think of a movement.

Relevant to the essence of dancing as a movement related to the psychomotor, the ability to perceive a movement (perceptual ability) according to Harrow (1972) combined cognitive ability and movement. The perceptual ability in dancing is related to stimulus and the ability to solve the problem with movement so someone that has kinesthetic intelligent needs to have sensory sensitivity to respond to action and chance in exploring movement variations.

Besides the ability to perceive move- ment, a choreographer needs to convey the movement in the form of dancing so that the meaning can be understood, communication is the basic of problem solving, the ability to communicate is the ability in conveying a message, both verbally and non-verbally. Communicating can be interpreted as conveying and gathering facts as well as the concept of knowledge in the form of voice, visual (Dimyati dan Mudjiono, 1999).

Similarly, according to Cartono, Funk in Dimyati dan Mudjiono (1999) the ability to communicate can be identified as: 1) the ability to express the argument in writing, 2) the ability to explain the result of observation, 3) the ability in arranging and delivering work result. Communicating can be interpreted as conveying and gathering facts, concepts, principle of knowledge in the form of writing, picture, and movement or performance; For example, by discussing, declaring, performing, expressing, reporting (in the form of verbal, written, movement, or performance)

According to Baroody (1993) there are five aspects of communication, one of them is related to movement. This aspect is representing, it is (a) the form as a result of problem translation or idea, (b) translation of a diagram or physical model inside a movement symbol or words, (c) translation of words into a table, diagram or graphic. Representation is useful for explaining a concept or idea, and can be used to find a strategy to solve a problem.

Dancing is a communication that can be expressed through movement. A good dance movement is a movement that can be understood by other people in the form of representative movements or symbols and movement meaning. Harrow (1972) described it as: non-discursive communication is the classification level composes of behaviors which can be labeled forms of movement comunication. These forms of movement behavior encompass a wide variety of conveying movements ranging from facial expresion, postures, and gestures to sophisticated modern dance choreographies. 
This shows that communication in dance movement is a level of classification that is arranged and can be made meaningful so that it can be communicated. The forms of conveying movement attitude include various movements such as facial expression, posture, and body movement for the choreography of sophisticated modern dancing.

Based on that, the major ability that is required for a choreographer in arranging a dance is kinesthetic intelligence but it is not the only one. Kinesthetic intelligent is also related to the time that is needed to be done through movement, but one of the abilities that is related to cognitive is movement perception. Meanwhile on the domain that is related to the affective result of the dance arrangement will be related to the ability to communicate the movement, because dance is a non-verbal expression that is used as a medium of communication.

Based on that, this research aimed to find an assessment model that can assess kinesthetic intelligence in arranging a dance from several influencing variables, both directly and indirectly. Those variables are movement perception, movement communication, dance arrangement ability, and kinesthetic intelligence.

\section{Method}

The research method used was quantitative correlation technique in order to give clear description between direct variable and indirect variable that influence the dependent variable. The associative hypothesis test was done to test the relation between movement perception, movement communication, kinesthetic intelligence, and arranging a dance. The double correlation test was used when the ability of movement perception and the ability of movement communication and kinesthetic intelligence influenced the ability to arrange a dance simultaneously.

To predict how the ability of movement perception, the ability of movement communication variable, and kinesthetic intelligence influenced on the dance arrangement, regression analysis test was done. Meanwhile, to find out the contribution of each variable to the dependent variables, partial correlation test was used.

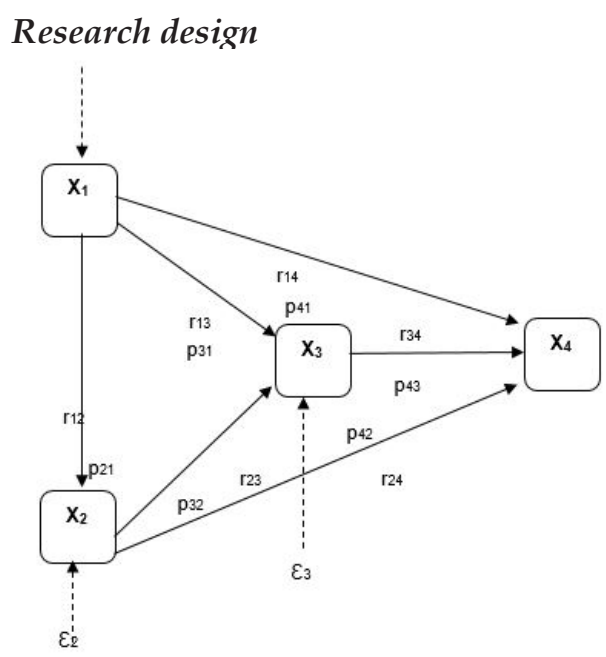

Figure 1. Structure of the Influence on the Hypothesized Research Variable Description:

X1: The Ability of Movement Perception

X2: The Ability of Movement Communication

$\mathrm{X} 3$ : Kinesthetic Intelligence

X4: Dance Arrangement

$\rho:$ Path Coefficient

$\varepsilon$ : Error or other factor (another variable)

\section{Population and Sample}

Population and sample in this research were collected by using purposive sampling technique. The sample was taken from the population that had suitable characteristics based on the specified requirement. The number of the sample was 17 people, taken from student population who took dance composition knowledge and choreography II class which consisted of 26 students, so it was around $80 \%$ of the population. The technique of sample collection was done by using formula (Bungin, 2005, p.105):

$$
n=\frac{N}{N\left(d^{2}\right)+1}
$$

Description:

$\mathrm{n}=$ the required number of the sample

$\mathrm{N}=$ number of population

$d=$ precision number $(90 \%$ or $a=0,1)$ 
The technique of collecting data was done through observation by providing observation sheet. The instrument sheet consisted: 1) dance arrangement instrument, 2) kinesthetic intelligence, 3) movement communication, and 4) movement perception. Those instruments were the variables that were predicted can be a smart kinesthetic measurement in dance arrangement.

\section{Kinesthetic Intelligence Instrument}

\section{Conceptual definition}

Kinesthetic intelligence was the ability to process, interpret, and express by using the whole or half of someone's body skillfully, based on the idea or emotion that can be expressed through movement, including handling things quickly and accurately to create a thing (Triana, 2012, p. 71).

\section{Operational definition}

Operationally kinesthetic intelligence in arranging a dance (Triana, 2012, p.72) was the score of the students that was obtained from observation test using measurement scale to find out (1) skill development that showed basic movement to discover physical movement ability, (2) the ability to receive stimulus (physical abilities) to measure the ability in responding to various reponses, (3) the ability to express, solve or create a problem solution through movement (perceptual ability) to discover perceptual ability from various themes, and (4) the ability to express idea and emotion through movement (nondiscursive communication).

\section{Plan}

The result of the instrument test was 1) movement perception instrument, 7 points valid with $a=0.92,2$ ) movement communication instrument, 10 points valid with $a=0.98,3$ ) kinesthetic intelligence movement instrument, 11 points valid with $\alpha=0.92,4$ ) arranging a dance instrument, 8 points valid with $\alpha=0.92$.

Pre-requirement test was done by using Lilliefors test to test the normaliza-

Table 1. The Plan of Kinesthetic Intelligence Instrument

\begin{tabular}{|c|c|c|c|c|}
\hline Variable & Dimension & Indikator & Point & Number \\
\hline \multirow{7}{*}{$\begin{array}{l}\text { Kinesthetic } \\
\text { Intelligence }\end{array}$} & basic movement & Movement reorganization & 1,2 & 2 \\
\hline & abilities & $\begin{array}{l}\text { Creating a coordinated se- } \\
\text { quence of movement of the } \\
\text { head, feet, and hand }\end{array}$ & 3,4 & 2 \\
\hline & $\begin{array}{l}\text { 2. physical abili- } \\
\text { ties }\end{array}$ & $\begin{array}{l}\text { 1. Doing sequence of move- } \\
\text { ment using property }\end{array}$ & $6,7,8$ & 3 \\
\hline & & $\begin{array}{l}\text { 2. Respond to the given } \\
\text { stimulus quickly and ac- } \\
\text { curately }\end{array}$ & 9,10 & 2 \\
\hline & $\begin{array}{l}\text { 3. perceptual } \\
\text { abilities }\end{array}$ & $\begin{array}{l}\text { 1. Themed movement per- } \\
\text { formance with music }\end{array}$ & 12,13 & 2 \\
\hline & & $\begin{array}{l}\text { 2. movement performance } \\
\text { based on specified dramatic }\end{array}$ & $14,15,16$ & 3 \\
\hline & $\begin{array}{l}\text { nondiscursive } \\
\text { communication }\end{array}$ & $\begin{array}{l}\text { Internalization of move- } \\
\text { ment based on the theme of } \\
\text { the dance }\end{array}$ & 19 & 1 \\
\hline
\end{tabular}


tion of the data. After the test was done, then regression linearity test was conducted. This test was conducted if the data and regression equation fulfilled the requirement. After that, path analysis was done by using path coefficient between exogenous variable and endogenous variable. Path coefficient hypothesis test was conducted using t-test to find out the influence of direct variable.

\section{Results and Discussion}

\section{Pre-Requirement Test}

The data were the ability of movement perception $\left(X_{1}\right)$, the ability of movement communication $\left(X_{2}\right)$, Kinesthetic Intelligence $\left(\mathrm{X}_{3}\right)$, and dance arrangement $(\mathrm{Y})$. In this research, the endogenous variable was Arranging a dance $(\mathrm{Y})$ and the intervening variable were Kinesthetic Intelligence $\left(X_{3}\right)$ and the ability of movement communication $\left(X_{2}\right)$, while the exogenous was the ability of movement perception $\left(X_{1}\right)$.

The result of the statistic of prerequirement test through normalization test showed: 1) the normalization test of measurement error regression of $\mathrm{Y}$ on $\mathrm{X}$ was $=0.0848,2)$ the normalization test of measurement error regression of $\mathrm{Y}$ on $\mathrm{X}_{2}$ was $=0.1092,3$ ) the normalization test of measurement error regression of $Y$ on $X_{3}$ was $=0.1434,4)$ the normalization test of measurement error regression of $X_{3}$ on $X_{1}$ was $=0.1347,5)$ the normalization test of measurement error regression of $X_{3}$ on $X_{2}$ was $=0.1465,6)$ the normalization test of measurement error regression of $\mathrm{X}_{2}$ on $\mathrm{X}_{1}$ was $=0.1549$. The result of error normalization test showed that it has smaller value than $(n=17 ; \alpha=0,05)$, the amount of the result was 0.206 . Therefore, the distribution of the data from each variable tended to form normal curve.

The next step was conducting correlation analysis by observing the distribution and signification of the relationship between exogenous variable pair and endogenous variable. Linearity test and regression signification were conducted through un-variant regression test, a li- nearity test and regression coefficient signification based on the constructed path. Below was the result of linearity test and signification test.

\section{Discussion}

Overall, there are six hypothesizes that were tested in this research and it was proven that there were two hypothesizes that showed linear relationship and significant influence, they were $X_{4}$ on $X_{3}$ and $\mathrm{X}_{2}$ on $\mathrm{X}_{1}$ moreover there were four hypothesizes that showed linear correlation but the influence among the variables were insignificant, they were $\mathrm{X}_{4}$ on $\mathrm{X}_{1} \mathrm{X}_{4}$ on $\mathrm{X}_{2}$ $X_{3}$ on $X_{1}$ and $X_{3}$ on $X_{2}$. The hypothesis test was 1$)$ regarding direct influence of movement perception ability $\left(X_{1}\right)$ on arranging a dance $\left.\left(X_{4}\right), 2\right)$ regarding direct influence of movement communication ability $\left(X_{2}\right)$ on arranging a dance $(X 4), 3$ ) regarding direct influence of Kinesthetic Intelligence (X3) on arranging a dance $(X 4), 4)$ regarding direct influence of movement perception ability (X1) on kinesthetic intelligence (X3), 5) regarding direct influence of movement communication ability (X2) on kinesthetic intelligence (X3), and 6) regarding direct influence movement perception ability (X1) on movement communication ability (X2).

The result of the research showed that movement perception ability, movement communication variable had an indirect influence on dance arrangement while kinesthetic intelligence has direct influence on dance arrangement. It would be discussed based on the finding and the result of hypothesis test as follow:

There was a correlation between movement perception ability and dance arrangement. The research result showed that there was an influence of movement perception on dance arrangement. This explained that movement perception ability was one of the abilities that supported psychomotor ability which was an ability to integrate physical function that coordinated brain as the center of information and control (Stankov, 1999), in which these information were received and processed, 
Table 2. The Result of Linearity Test and Regression Signification Test

\begin{tabular}{|c|c|c|c|c|c|c|}
\hline \multirow[b]{2}{*}{$\operatorname{Reg}$} & \multirow[b]{2}{*}{ Equation } & \multicolumn{2}{|c|}{ Signification Test } & \multicolumn{2}{|c|}{ Linearity Test } & \multirow[b]{2}{*}{ Conclusion } \\
\hline & & $\mathrm{F}_{\text {hitung }}$ & $\begin{array}{c}F_{\text {tabel }} \\
\alpha=0,05\end{array}$ & $\mathrm{~F}_{\text {hitung }}$ & $\begin{array}{c}F_{\text {tabel }} \\
\alpha=0,05\end{array}$ & \\
\hline $\mathrm{X}_{4}$ on $\mathrm{X}_{1}$ & $\hat{X}_{4}=127.325-0.519 X_{1}$ & $2.456^{*}$ & 4.543 & $0.636^{\mathrm{ns}}$ & 4.735 & $\begin{array}{l}\text { Insignificant/ Li- } \\
\text { nier Regression }\end{array}$ \\
\hline $\mathrm{X}_{4}$ on $\mathrm{X}_{2}$ & $X_{4}=154.297-0.206 X_{2}$ & $0.916^{*}$ & 4.543 & $0.475^{\mathrm{ns}}$ & 4.099 & $\begin{array}{l}\text { Insignificant/ Li- } \\
\text { nier Regression }\end{array}$ \\
\hline $\mathrm{X}_{4}$ on $\mathrm{X}_{3}$ & $X_{4}=164.257-0.257 X_{3}$ & $40.039 * *$ & 4.543 & $4.611^{\mathrm{ns}}$ & 8.745 & $\begin{array}{c}\text { Very Significant/ } \\
\text { Linier Regres- } \\
\text { sion }\end{array}$ \\
\hline $\mathrm{X}_{3}$ on $\mathrm{X}_{1}$ & $X_{3}=112.903-0.278 X_{1}$ & $1.637^{*}$ & 4.543 & $1.476^{\mathrm{ns}}$ & 4.735 & $\begin{array}{l}\text { Insignificant/ Li- } \\
\text { nier Regression }\end{array}$ \\
\hline $\mathrm{X}_{3}$ on $\mathrm{X}_{2}$ & $X_{3}=104.880-0.151 X_{2}$ & $0.272^{*}$ & 4.543 & $0.624^{\mathrm{ns}}$ & 4.099 & $\begin{array}{l}\text { Insignificant/ Li- } \\
\text { nier Regression }\end{array}$ \\
\hline $\mathrm{X}_{2}$ on $\mathrm{X}_{1}$ & $X_{2}=50.613+0.550 X_{1}$ & $14.535^{* *}$ & 4.543 & $1.425^{\mathrm{ns}}$ & 4.735 & $\begin{array}{l}\text { Very Significant/ } \\
\text { Linier Regres- } \\
\text { sion }\end{array}$ \\
\hline
\end{tabular}

Table 3. Result Recapitulation of Hypothesis Test

\begin{tabular}{cccccc}
\hline Hypothesis & Statistic Test & $\mathrm{t}_{\text {hitung }}$ & $\mathrm{t}_{\text {tabel }}$ & Decision & Conclusion \\
\hline $\begin{array}{c}\text { Movement perception ability } \\
\text { directly influenced dance ar- } \\
\text { rangement }\end{array}$ & $\begin{array}{c}\mathrm{H}_{0}: \beta_{41} \leq 0 \\
\mathrm{H}_{1}: \beta_{41}>0\end{array}$ & -0.572 & 2.110 & $\mathrm{H}_{0}$ accepted & $\begin{array}{c}\text { Had no influ- } \\
\text { ence }\end{array}$ \\
$\begin{array}{c}\text { Movement communication } \\
\text { ability directly influenced } \\
\text { dance arrangement }\end{array}$ & $\begin{array}{c}\mathrm{H}_{0}: \beta_{42} \leq 0 \\
\mathrm{H}_{1}: \beta_{42}>0\end{array}$ & -0.287 & 2.110 & $\mathrm{H}_{0}$ accepted & $\begin{array}{c}\text { Had no influ- } \\
\text { ence }\end{array}$ \\
$\begin{array}{c}\text { Kinesthetic Intelligence } \\
\text { directly influenced dance ar- } \\
\text { rangement }\end{array}$ & $\begin{array}{c}\mathrm{H}_{0}: \beta_{43} \leq 0 \\
\mathrm{H}_{1}: \beta_{43}>0\end{array}$ & 5.493 & 2.110 & $\mathrm{H}_{0}$ rejected & $\begin{array}{c}\text { Had direct } \\
\text { influence }\end{array}$ \\
$\begin{array}{c}\text { Movement perception ability } \\
\text { directly influenced kinesthet- } \\
\text { ic intelligence }\end{array}$ & $\begin{array}{l}\mathrm{H}_{0}: \beta_{31} \leq 0 \\
\mathrm{H}_{1}: \beta_{31}>0\end{array}$ & -1.024 & 2.110 & $\mathrm{H}_{0}$ accepted & $\begin{array}{c}\text { Had no direct } \\
\text { influence }\end{array}$ \\
$\begin{array}{c}\text { Movement communication } \\
\text { ability directly influence } \\
\text { kinesthetic intelligence }\end{array}$ & $\begin{array}{c}\mathrm{H}_{0}: \beta_{32} \leq 0 \\
\mathrm{H}_{1}: \beta_{32}>0\end{array}$ & 0.290 & 2.110 & $\mathrm{H}_{0}$ accepted & $\begin{array}{c}\text { Had no direct } \\
\text { influence }\end{array}$ \\
$\begin{array}{c}\text { Movement perception ability } \\
\text { directly influence movement } \\
\text { communication ability }\end{array}$ & $\begin{array}{c}\mathrm{H}_{0}: \beta_{21} \leq 0 \\
\mathrm{H}_{1}: \beta_{21}>0\end{array}$ & 3.570 & 2.110 & $\mathrm{H}_{0}$ rejected & $\begin{array}{c}\text { Had direct } \\
\text { influence }\end{array}$ \\
\hline
\end{tabular}

then transferred by motoric neurons into a movement (Harrow, 1972). However, movement perception ability did not directly influence or relate on dance arrangement, this was similar to the statement of Blumfeld-Jones (2009) because this ability was a process self-actualization, not a product of it, and not only the ability to intergrate the brain function that was expressed in movement. Arranging a dance needed a complex ability, not only an ability to perceive movement but also other influenced variables. The ability to perceive movement was a part of psychomot taxono- 
mi that was stated by Harrow (1972), that was shown in the third level in theory of psychomotor. Therefore, arranging a dance was not an ability that directly related to psychomotor even though psychomotor was one of the supporting elemnt in arranging a dance.

There was a correlation between movement communication ability and arranging a dance. Ability to communicate 1) expressing a written idea, 2) ability to explain the result of obeservation, 3) ability to arrange and deliver work result. In dancing, the movement was a tool of communication that was needed to be understood by other people in form of representational movement or symbols and meaning of movement. Conveying movement was the sixth level of the psychomotor theory that was stated by Harrow (1972), this level was the highest level of psychomotor. However, in arranging a dance, psychomotor was one of the supporting parts. Hence, the movement communication ability had a correlation toward arranging a dance even though it had no direct influence.

There was kinesthetic intelligence in arranging a dance. Kinesthetic intelligence was one of the intelligences that according to Gardner (2003) was an ability to solve problem or product by using the whole or half part of the human body that was usually possessed by a dancer, an athlete, a surgeon, and a craftman. This intelligence was needed by a choreographer in arranging a dance; therefore, in could be said that kinesthetic intelligence has correlation and direct influence toward dancing arrangement. This was similar to the statement of Roberts, Stankov, Pallier, Dolph (1997) that classified cognitive as the kinesthetic ability inside the structure of intelligence, according to them, one's ability could be measured through his kinesthetic ability.

There was a correlation between movement perception ability and kinesthetic intelligence. As stated by Harrow (1972) that movement perception ability was one of the abilities that intgrate phsycal function that coordinated brain as the center of information and control, in which this information were received and processed, then transferred by motoric neurons to become a movement. Brain function was a mental ability that involved process of thinking rationally. Therefore, there was a relation between movement perception and knesthetic intelligence even though it had no direct influence. This was in line with the statement from Bulmenfeld-Jones (2009) as a choreographer, that kinesthetic intelligence was not only the ability to do a difficult movement, memorize the sequence of movement, or the ability to create movement, because there were a process of self-actualization toward the need to do a movement.

There was a correlation between movement communication and kinesthetic intelligence. Kinesthetic intelligence allowed human to build an importan relationship between mind and body so that it allowed the human body to manipulate object, create movement, and ability to communicate using movement such as facial expression (Harrow, 1972). Based on that, there are connections between conveying movement and kinesthetic intelligence even though it had no direct influence.

There was a correlation between movement perception ability and conveying movement. The ability to perceive a movement was a result of brain function that was expressed into a movement pattern, the process that was perceived need to be communicated. Therefore, according to Lwin (2008) this was a psychomotor ability that combined mental interpretation with a physical response. A dance was often a result of a response that was resulted from the stimulus, then it was expressed through movement (Dinny, 2012). Therefore, movement perception ability had a direct influence on conveying movement.

\section{Conclusion}

This research aimed to find variables information that connected perceiving movement ability, communicating ability, kinesthetic intelligence, dance arrangement, both directly and indirectly. The correlati- 
on could be used as the basic of kinesthetic measurement in arranging dance. Based on the result of the research, it can be concluded that:

There was a correlation between perceiving movement ability and arranging a dance. The ability to perceive movement was the third level of psychomotor theory, because psychomotor was not directly related to the ability to arrange a dance so it could be concluded that perceiving movement ability had a correlation with arranging a dance but had no direct influence on it.

There was a correlation between conveying movement and arranging a dance. Conveying movement ability was the highest level of psychomotor theory, because psychomotor was not directly related to the ability to arrange a dance so it can be concluded that conveying movement ability had correlation with arranging a dance but had no direct influence

There was a correlation between kinesthetic intelligence and arranging a dance. Kinesthetic intelligence was related to a profession that closely involved psychomotor ability, in this case choreographer. Therefore, it can be concluded that there was a significant correlation between kinesthetic intelligence and arranging a dance.

There was a correlation between perceiving movement ability and kinesthetic intelligence. Perceiving movement ability was needed by human brain work the same as intelligence, the difference was in the movement, kinesthetic intelligence was closely related to speed and accuracy in expressing movement that was related to dance, so the expressed movement became meaningful. So, it can be concluded that there was correlation between perceiving movement ability and kinesthetic intelligence even though it was not significant or had no direct influence.

There was a correlation between conveying movement ability and kinesthetic intelligence. In dancing, the conveying movement ability was related to a visual expression that needed to be understood by people. So, there was correlation between conveying movement ability and kinesthetic intelligence even though it had no direct influence

There was a correlation between perceiving movement ability and conveying movement. Both abilities could be found in psychomotor theory so the result of the human brain in perceiving movement then was communicated through visualization to become a dance. Therefore, there was a significant direct correlation between perceiving movement ability and conveying movement.

Based on the finding from the analysis of the variables, there was direct correlation such as perceiving movement with conveying movement variable, and kinesthetic intelligence variable with arranging a dance. Therefore, it was suggested to not only pay attention to the perceiving and conveying movement ability but also on kinesthetic intelligence when measuring one's ability in arranging a dance. However, kinesthetic intelligence could be improved by practicing and structural mentoring through perceiving and conveying movement ability.

\section{References}

Amstrong, T. (2002). Sekolah Para Juara: Menerapkan Multiple Intelligences di Dunia Pendidikan, Translated by Yudhi Murtanto. Bandung: Kaifa.

Almeida, L. S., Prieto, M. D., Ferreira, A. I., Bermejo, M. R., Ferrando, M., \& Ferrándiz, C. (2010). Intelligence assessment: Gardner multiple intelligence theory as an alternative. Learning and Individual Differences, 20(3), 225-230.

Blumenfeld-Jones, D., Gress, J. R., \& Purpel, D. (2009). Bodily-Kinesthetic Intelligence and Dance Education: Critique, Revision, and Potentials for the Democratic Ideal. The Journal of Aesthetic Education, 43(1), 59-76.

Gerald, G. (2011). Writing and Multiple Intelligences - Gerald Grow's Home Page. Retrieved July 6, 2017, from http://longleaf.net/wp/articles- 
teaching/writing-multiple-intelligences/

Benjamin, B. S. (1979). Taxonomy of Educational Objectives: Handbook I Cognitive Domain. New York: Longman, Inc.

Bungin, B. (2005). Metodologi Penelitian Kuantitatif . Jakarta: Prenada Media.

Cangelosi, J. S. (1995). Merancang Tes Untuk Menilai Prestasi Siswa. Bandung: ITB.

Dimyati \& Mudjiono. (1999). Belajar dan Pembelajaran. Jakarta: Rineka Cipta.

Gardner, H. (2003). Multiple Intelligence: Kecerdasan Majemuk Teori dalam Praktik. Translated by Alexander Sindoro, Batam: Interaksara.

Grow, G. (2011). Writing and Multiple Intelligences - Gerald Grow's Home Page. Retrieved May 6, 2016, retrieved from http://longleaf.net/ $\mathrm{wp} /$ articles-teaching/writing-multiple-intelligences/

Harrow, A. J. (1972). A Taxonomy of The Psychomotor Domain: A Guide for Developing Behavioral Objectives. New York : Longman Inc.

Hariyanto, D. (2009). Kecakapan Persepsi Dalam Pembelajaran Keterampilan Psikomotorik Kesegaran Jasamani dan Seni Gerak. Harmonia: Journal of Arts Research and Education, 9(1).

Lwin, M., Khoo, A., Lyen, K., \& Sim, C. (2008). How to Multiple Your Child"s Intelligence, translated by Christine Sujana. Jakarta: PT Indeks.

Meri, L. (1965). Dance Composition: The Basic Elements. Massachusetta: Jaccob's
Pillow Dance Festival, Inc.

Murgiyanto, S. (1983). Koreografi: Pengetahuan Dasar Komposisi Tari. Jakarta: Direktorat Jenderal Pendidikan Dasar dan Menengah Departemen Pendidikan dan Kebudayaan.

Reynolds, C. R., Livingston, R. B., Willson, V. L., \& Willson, V. (2009). Measurement and Assessment in Education. New Jersey: Pearson Education.

Roberts, R. D., Stankov, L., Pallier, G., \& Dolph, B. (1997). Charting the cognitive sphere: Tactile-kinesthetic performance within the structure of intelligence. Intelligence, 25(2), 111-148.

Singarimbun, M. \& Effendi, S. (1989). Metode Penelitian Survai. Jakarta: LP3ES.

Suryabrata, S. (2000). Pengembangan Alat Ukur Psikologis Yogyakarta: Andi.

Sukenik, R. (1997). Evaluating Choreography. Performing Arts Journal, 57(3).

Stankov, L., Seizova-Cajić, T., \& Roberts, R. D. (2001). Tactile and kinesthetic perceptual processes within the taxonomy of human cognitive abilities. Intelligence, 29(1), 1-29.

Triana, D. D. (2012). Disertasi: Pengaruh Penilaian Kinerja dan Penguasaan Pengtahuan Komposisi Tari Terhadap Kecerdasan Kinestetik Peserta didik dalam Menata Tari (Eksperimen pada Peserta didik UNJ dan UPI Bandung), Jakarta: Pascasarjana Universitas Negeri Jakarta. 